\title{
Etiology and Clinical Course of Patients with Severe Influenza/Acute Respiratory Infection Requiring Hospitalization During the 2015-2016 Influenza Season
}

\author{
Ayşe Batırel, ${ }^{1}$ Semih Korkut, ${ }^{2}$ Recep Demirhan, ${ }^{3}$ Ayşe Karaaslan, ${ }^{4}$ \\ Banu Eler Çevik, ${ }^{5}$ Sevda Şener Cömert, ${ }^{6}$ Engin Ersin Şimşek ${ }^{7}$
}

\section{'Department of Infectious Diseases and Clinical Microbiology ${ }^{2}$ Department of Emergency Medicine 3Department of Thoracic Surgery ${ }^{4}$ Department of Pediatrics ${ }^{5}$ Department of Anesthesiology and Reanimation \\ ${ }^{6}$ Department of Pulmonary Diseases ${ }^{7}$ Department of Family Medicine All, University of Health Sciences, Kartal Dr. Lütfi Kırdar Training and Research Hospital, İstanbul, Turkey}

Submitted: 15.11.2017 Accepted: 21.11.2017

Correspondence: Ayșe Batırel, Kartal Dr. Lütfi Kırdar Eğitim ve Araştırma Hastanesi, Enfeksiyon Hastalıkları ve Klinik Mikrobiyoloji, İstanbul, Turkey

E-mail: aysebatirel@yahoo.com

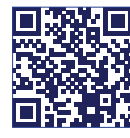

Keywords: HINI; influenza; respiratory viruses; severe acute respiratory infection.

\begin{abstract}
Objective: The aim of the present study was to determine the etiological profile, clinical course, and outcome of patients hospitalized with severe influenza during the 2015-2016 influenza season.

Methods: Patients with severe influenza who were admitted to the emergency department of the hospital between December I, 2015 and March I5, 2016 and who required admission were included. The presence of dyspnea, tachypnea, tachycardia, hypotension, hypoxia, mental status changes, severe dehydration, or chest X-ray compatible with bronchopneumonia/ pneumonia were considered "severe influenza." Nasopharyngeal aspirate specimens from all patients were tested for respiratory viruses using the reverse transcriptase-polymerase chain reaction technique.
\end{abstract}

Results: Of a total of 95 hospitalized patients, 65 patients (68.4\%; 38 adults and 27 children) were virus-positive. The etiological virus was 42 (64.6\%) cases of influenza A (HINI), 9 (13.8\%) of influenza $A(H 3 N 2)$, and 5 (7.7\%) of coronavirus. Six patients (9.2\%) were pregnant. Only I pregnant patient died, due to HINI influenza. Fifteen (23\%; 14 adults and I child) required follow-up in the intensive care unit (ICU). Nine adult patients died [7 due to influenza A (6 HINI, I H3N2), I due to human metapneumovirus, I due to coronavirus], but all of the children survived. The case-fatality rate of $\mathrm{HINI}$ infection was $14.3 \%$.

Conclusion: Two-thirds of the admitted patients had an influenza A HINI infection. Seven (16.7\%) of them required ICU follow-up. The HINI case-fatality rate was $14.3 \%$. Patients with risk factors who have severe influenza should be hospitalized.

\section{INTRODUCTION}

Influenza outbreaks occur every year because influenza viruses change their antigenic properties (i.e., the envelope glycoproteins: hemagglutinin, abbreviated " $\mathrm{H}$ " and neuraminidase, abbreviated "N") very frequently. Major changes in hemagglutinin and neuraminidase are called "antigenic shifts," while minor changes in these envelope glycoproteins are referred to as "antigenic drifts." Antigenic shifts lead to epidemics and pandemics of influenza A. ${ }^{[1]}$ Three major subtypes of hemagglutinins $(\mathrm{HI}, \mathrm{H} 2$, and $\mathrm{H} 3$ ) and 2 subtypes of neuraminidases (NI and N2) have been described in influenza $A$ viruses that are pathogenic for humans. Influenza B viruses have antigenic drifts in the hemagglutinin glycoprotein. In late March 2009 and early April 2009, an epidemic of patients with HINI influenza A virus infection was detected. ${ }^{[2,3]}$ The HINI strain involved in that epidemic emerged after a genetic mutation of influenza viruses in pigs (swine influenza), birds (avian influenza), and humans. In June 2009, the World Health Organization (WHO) announced a global pandemic, the highest stage of their classification system. ${ }^{[4]}$ The pandemic was not declared to have ended until August 2010..$^{[5]}$ It had a high morbidity and mortality rate among children and young adults 
worldwide. ${ }^{[6]}$ Although most of the reported mortality was observed in patients with various underlying chronic illnesses, one-third of the hospitalized patients with severe influenza had no concomitant diseases and were otherwise healthy. ${ }^{[7]}$ When compared with the general population, the mortality rate of pregnant women with HINI influenza $A$ was higher. ${ }^{[8,9]}$ Obesity was also determined to be an independent risk factor for severe influenza. ${ }^{[10]}$ The Centers for Disease Control and Prevention (CDC) in the United States of America (USA) reports influenza activity regularly by following up influenza virus isolates worldwide in collaboration with the WHO. During the influenza season, surveillance data is updated weekly on the website of CDC. ['I] Moreover, "FluNet," a global influenza virus surveillance database is available on the website of the WHO. ${ }^{[12]}$ According to the data reported on these reference sites (as shown in the graph obtained from the WHO website in Fig. I), during the 2015-2016 influenza season, the number of influenza cases increased to epidemic level starting in the $50^{\text {th }}$ week of 2015 and lasting until the $20^{\text {th }}$ week of 2016 . Influenza surveillance has been performed in our country since 2005. In 20I5, the Turkish Public Health Association started an active surveillance program of severe acute respiratory infection (SARI) cases diagnosed in hospitals of 5 different cities around Turkey. During the 2015-2016 influenza season, the first laboratory-confirmed case of influenza was detected in the $42^{\text {nd }}$ week of 2015 . The subtyping revealed that the majority of the influenza viruses isolated were $\mathrm{HINI}$ and $\mathrm{H} 3 \mathrm{~N} 2$. As reported by the WHO, the first laboratory-confirmed case of influenza in the European region was detected in the 40th week of 2015. The sub-typing of influenza viruses isolated in European coun- tries was reported to be an influenza $A(\mathrm{HINI})$ virus in the majority of cases, followed by an influenza $B$ virus. Given that knowledge, the aim of this study was to determine the etiological profile, clinical course, and outcome of the patients hospitalized with severe influenza/SARI in a tertiary medical center during the 2015-2016 influenza season.

\section{MATERIAL AND METHODS}

A retrospective descriptive case series study was performed. Patients with severe influenza who were admitted to the emergency department of the hospital between December I, 2015 and April 15, 2016 and who required hospital admission were included in the study. Patient management was established according to the Turkish Ministry of Health (TMH) recommendations. Any patient with a fever $>38^{\circ} \mathrm{C}$ (axillary measurement and the cause of the fever cannot be explained by any other reason) and with at least I of the following symptoms: i) myalgia, ii) sore throat, iii) headache, iv) nasal discharge, or v) cough and dyspnea was regarded as a "possible influenza case." The inclusion criteria for children with influenza-like illnesses were at least I of the following: i) temperature $\geq 37.8^{\circ} \mathrm{C}$, ii) headache, iii) myalgia, iv) malaise, and at least I of the following: i) cough, ii) sore throat, or iii) shortness of breath, and hospital admission within 7 days of the appearance of clinical conditions, according to European Centre for Disease Prevention and Control (ECDC) definition. ${ }^{[13]}$

If there is any indication for hospitalization or any increased risk of morbidity and mortality due to influenza (as listed below), a possible influenza case is admitted to

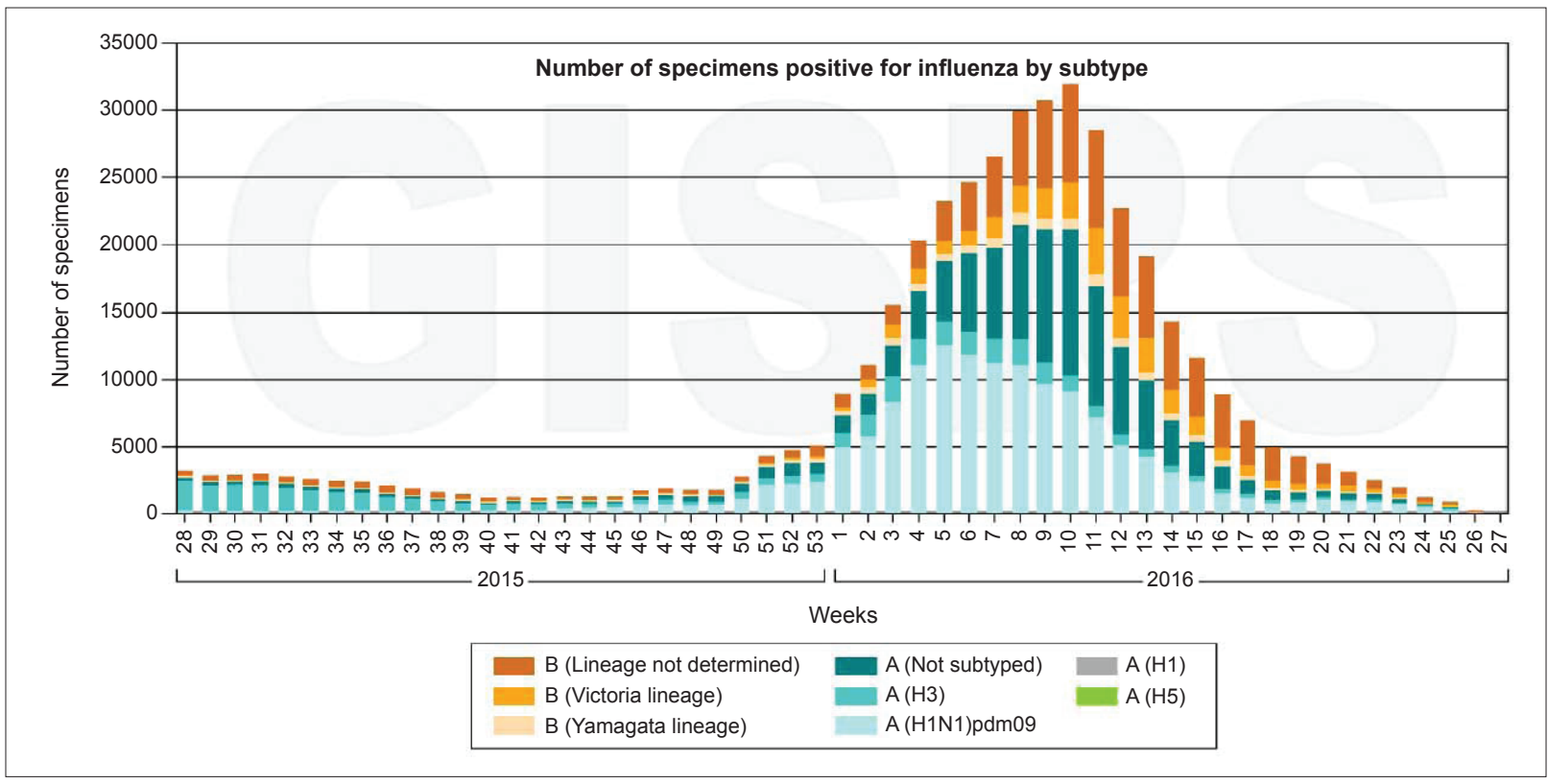

Figure 1. Global circulation of influenza viruses in the 2015-2016 influenza season as reported by the World Health Organization. [FluNet (www.WHO.int/flunet)]. 
the hospital and immediate antiviral treatment is initiated. Indications for hospitalization include:

- Dyspnea or respiratory distress,

- Changes in vital signs,

- Hypoxia (oxygen saturation $\leq 92 \%$ by pulse oxymetry),

- Mental state changes, and

- Severe dehydration.

Indications for admission to the intensive care unit (ICU) include:

- Unresolved hypoxia resistant to therapy, progressive hypercapnia,

- Hemodynamic disturbances, and

- Sepsis and septic shock.

Patients with an increased risk of morbidity and mortality due to influenza include:

- Patients $\geq 65$ years and $<2$ years of age,

- Pregnant women,

- Those residing in daily care and elderly care centers,

- Patients with chronic renal disease,

- Patients with asthma or chronic pulmonary diseases,

- Patients with heart or coronary artery disease,

- Patients with hematological diseases,

- Diabetic patients,

- Patients with neurological diseases,

- Patients with metabolic diseases,

- Patients with chronic liver disease,

- Immunocompromised patients,

- Obese patients,

- Healthcare workers, and

- Patients $>6$ months and $<18$ years of age who require long-term acetylsalicylate use.

The presence of dyspnea, tachypnea, tachycardia, hypotension, hypoxia, mental status changes, severe dehydration, or a chest X-ray compatible with bronchopneumonia/pneumonia was considered "severe influenza." Nasopharyngeal swab/aspirate specimens were obtained from all hospitalized patients and tested for respiratory viruses using the reverse transcriptase-polymerase chain reaction (RT-PCR) method. The diagnostic test of molecular typing was performed by the Istanbul Public Health Laboratory in the context of a SARI surveillance study. The inclusion criteria were:

- Reference to the emergency department, or the outpatient polyclinics of infectious diseases, pediatrics, pulmonary medicine, or family medicine with the initial diagnosis of influenza during the 2015-2016 influenza season,

- Management according to the influenza case management algorithm developed by the TMH (Fig. 2),

- Hospitalization because of severe influenza and,

- Provision of a specimen of nasopharyngeal aspirate for diagnosis.

Patients with an initial diagnosis other than influenza/ influenza-like illnesses or SARI and those who were not admitted to the hospital for inpatient management were excluded from the study.

The primary endpoints were exclusion of influenza diagnosis by negative PCR test results, mortality, and discharge from hospital. All of the patients hospitalized with the initial diagnosis of severe influenza were administered oral oseltamivir therapy as soon as possible after nasopharyngeal aspirate specimens had been obtained (In adults: 75 mg 2 times daily for 5 days; in children: the dose and duration of oseltamivir was determined by the pediatricians according to the guideline recommendations).

\section{RESULTS}

Nasopharyngeal aspirate samples of a total of 95 hospitalized patients were tested. Among them, 30 (3I.6\%) specimens were negative for any respiratory viruses. Of $65(68.4 \%)$ virus-positive patients, 38 (58.5\%) were adults and $27(41.5 \%)$ were children (pediatric age group at our center: $\leq 14$ years). The mean age of the adult patients was 52.3 years (range: 19-86 years), and 24 (63.2\%) of them were female. The mean age of the children was 2.3 years, or 26.9 months (range: I-III months), and I4 (5I.9\%) were female. The distribution of etiological viruses was: 42 (64.6\%; I 8 children, 24 adults) cases of influenza A (HINI) virus, 9 (I3.8\%; 5 children, 4 adults) of influenza $A$ (H3N2) virus, 5 (7.7\%; 3 adults, 2 children) of coronavirus. In addition, among the children, there was I case of concomitant coronavirus, human metapneumovirus (HMPV), and respiratory syncytial virus (RSV) co-infection, as well as I case of concomitant coronavirus and human bocavirus (HBoV) co-infection. Among the adults, 2 cases of HMPV, I influenza B virus, I parainfluenza 4 virus, I rhinovirus plus RSV co-infection, I RSV, and I adenovirus were isolated. Six $(9.2 \%)$ patients were pregnant. Among the pregnant patients, 2 had HINI, another 2 had H3N2, I had RSV, and the remaining patient had an adenovirus infection. The mean number of gestational weeks was $25.2 \pm \mathrm{II}$ weeks (range: II-37 weeks). Only I pregnant patient required ICU follow-up and unfortunately, she died due to HINI influenza. The duration of mean hospital stay of the patients was 9.2 \pm 7 days (range: I-3I days). Only I5 (23\%; 14 adults, I child) patients required follow-up in the ICU. Nine of the patients managed in the ICU had an HINI virus infection. Among the ICU patients with influenza, a total of 9 adults died $[7$ due to an influenza A virus infection (6 of HINI, I of H3N2), I due to HMPV infection, another I due to a coronavirus infection]. Fortunately, all of the children hospitalized with the diagnosis of influenza/ influenza-like illness (SARI) survived. The case-fatality rate of HINI infection among the hospitalized patients was

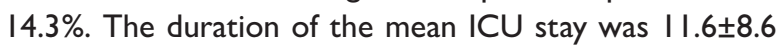
days (range: $\mathrm{I}-30$ days). None of the patients had been vaccinated against influenza. 


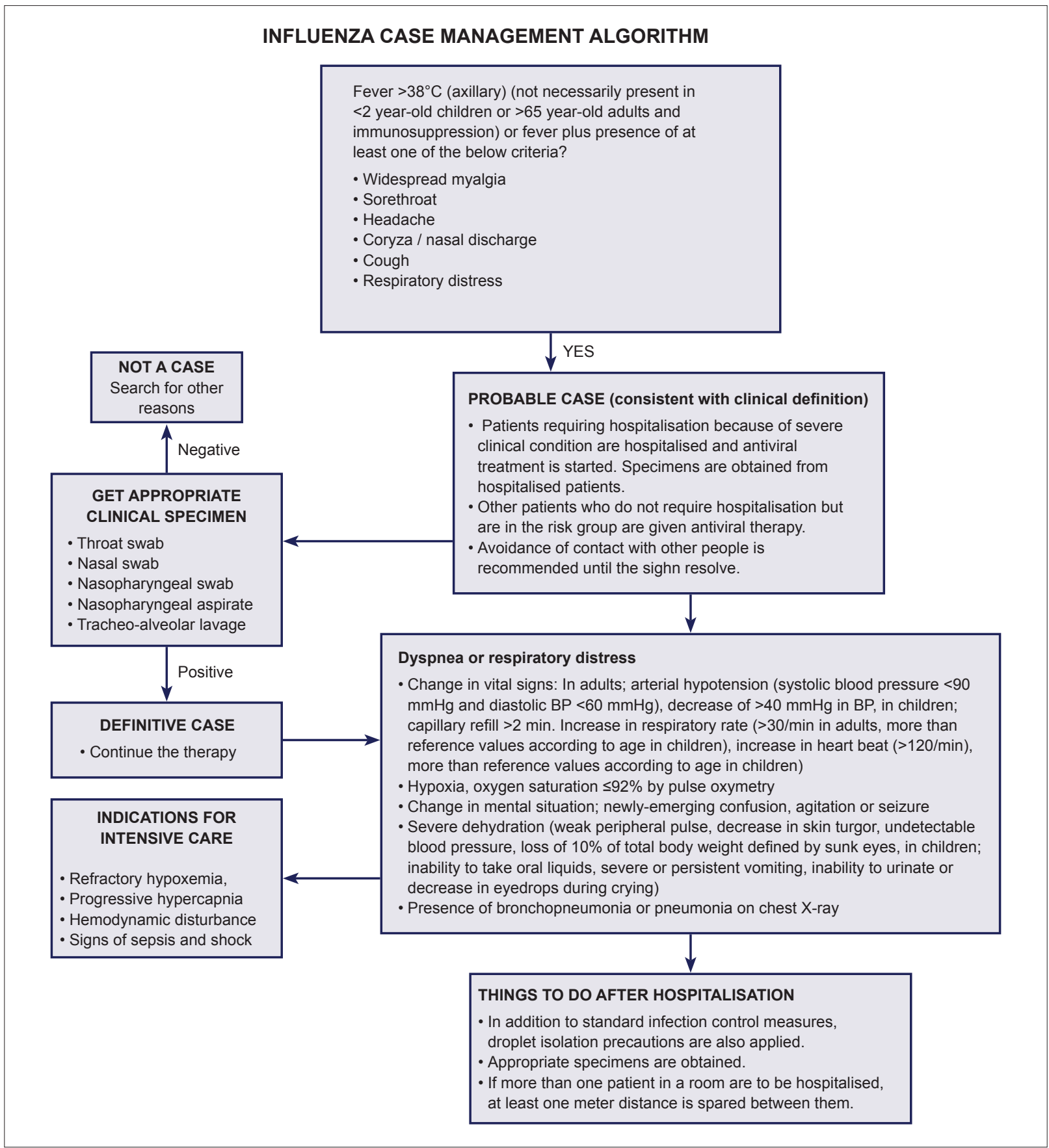

Figure 2. Influenza Case Management Algorithm developed by the Turkish Ministry of Health (grip.gov.tr/saglik-personeli-icin.../282influenza-vaka-yonetim-algoritmasi.html).

\section{DISCUSSION}

During an outbreak, the diagnosis of influenza can be made clinically. Adults with mild disease who are younger than 65 years of age and who have no high-risk factors usually do not require laboratory testing or treatment. ${ }^{[14]}$ In hospitalized patients with SARI, laboratory testing (e.g., RT-PCR) is necessary for an accurate diagnosis in order to establish specific treatment. The Infectious Diseases Soci- ety of America (IDSA) published guidelines on the diagnosis and management of influenza in 2009. ${ }^{[15]}$ The CDC has also published documents on the diagnosis of influenza. [16] We obtained nasopharyngeal swabs for influenza testing. Although nasopharyngeal aspirates or washings have been reported to be more sensitive than nasopharyngeal swabs, ${ }^{[17]}$ the clinicians in our study preferred swabs, since they are easier to obtain. Nearly one-third of the specimens were negative for any respiratory virus. If we had 
been able to get nasopharyngeal aspirates or washings, the positivity rate might have been higher. Tanriover et al. ${ }^{[18]}$ reported a rate of $18.4 \%$ influenza-positive, with an HINI strain predominance in their study, which involved patients in 5 tertiary care hospitals during the 2015-2016 influenza season in Turkey. In our study, more than half of the patients were adults and more than half were female. The mean age of the children hospitalized with SARI was 2 years, and more than half of them were also female.

Influenza with fever, headache, myalgia, nonproductive cough, sore throat, and nasal discharge is referred to as "uncomplicated influenza."[19] We use the term "severe influenza" or "complicated influenza" for patients having any indications for hospitalization or any complications of influenza (e.g., pneumonia, which is the most common complication, or muscle and/or central nervous system complications). Only patients hospitalized with a presumptive diagnosis of severe influenza were included in this study.

We detected different etiological viruses in this influenza season. Two or 3 different influenza strains may circulate concurrently in an influenza season. ${ }^{\left[{ }^{\prime \prime}\right]}$ The most common etiological agent (nearly 65\%) was the HINI influenza $A$ virus, followed by the H3N2 influenza $A$ virus. Different influenza viruses may cause diseases of different severity. In one study, no significant differences were reported between influenza $A$ and $B$ infections among $\geq 65$-year-old hospitalized adults regarding median length of stay in the hospital, admission to the ICU, or mortality. ${ }^{[20]}$ The most severe disease was caused by the H3N2 subtype of the influenza $A$ virus, followed by influenza $B$ viruses. The HINI influenza A virus caused milder disease. ${ }^{[21]}$ However, the pandemic HINI influenza A caused more severe disease than $\mathrm{H} 3 \mathrm{~N} 2$ influenza $A$ or influenza $B$ in hospitalized patients during the 2010-20II influenza season. ${ }^{[22]}$ Sporadic cases of other respiratory viruses have also been observed, although fewer in number than influenza viruses. In a review of upper respiratory infections in older adults that included 497 episodes in total from the influenza season of 1992-1994, the etiological pathogen was identified in $43 \%$ of the patients. ${ }^{[23]}$ Influenza $A$ or $B$ viruses accounted for only $10 \%$. The most common pathogens were rhinoviruses (more than half), followed by coronaviruses (one-fourth).

Among respiratory viruses, coronavirus causes approximately $5 \%$ to $10 \%$ of severe, community-acquired, upper respiratory tract infections in adults. Coronavirus infection occurs sporadically or in outbreaks. No specific treatment is recommended for coronavirus infections, aside from supportive care. ${ }^{[24]}$ Six cases of coronavirus infection were detected in our study. RSV also causes acute respiratory tract illness in the form of seasonal outbreaks, like influenza viruses, during winter. ${ }^{[25,26]}$ It affects patients of all ages, but most commonly children younger than I year of age. ${ }^{[27]}$ It is usually self-limited, but it can cause severe infection in high-risk patients. Parainfluenza virus (PIV), metapneumovirus, influenza virus, rhinovirus, coronavirus, bocavirus, and adenovirus should be considered in the differential diagnosis of RSV. We detected 3 cases of concomitant RSV infection along with other respiratory viruses. HMPV was discovered in 200I. ${ }^{[28]}$ It is a paramyxovirus that causes self-limited upper and lower respiratory tract infections in patients of all ages. Symptomatic disease most often occurs in young children or older adults. Patients with severe pneumonia and acute respiratory distress syndrome require hospitalization. At present, no specific antiviral therapy is available. ${ }^{[2]}$ In our study, I child patient had concomitant coronavirus, HMPV, and RSV coinfection, and 2 adults had HMPV infection. HBoV was isolated in 2005. It is a parvovirus that is found in both respiratory and stool samples of children of 6 to 24 months of age with SARI. ${ }^{[30]}$ It is frequently detected in children with respiratory disease in combination with other viruses or bacteria. In our study, I case of concomitant coronavirus and $\mathrm{HBoV}$ co-infection was observed. Moesker et al. ${ }^{[3 !]}$ reported that they found 178 and 366 cases of $\mathrm{HBoV}$ and RSV, respectively, in their study of 990 patients who tested positive for a respiratory virus with RT-PCR. Forty-nine (28\%) HBoV-positive patients and 72 (20\%) RSV-positive patients were admitted to the ICU. PIVs cause mild upper respiratory tract infections in adults and children. ${ }^{[32]}$ In immunocompetent adults, they usually cause asymptomatic or self-limited upper respiratory tract infections. However, in immunocompromised and older patients, they can cause life-threatening lower respiratory tract infections. At present, no specific antiviral drug is available for the treatment of severe cases. ${ }^{[33]}$ Between 1990 and 2004, more than 40,000 cases of PIV were detected in a surveillance study that included children and adults in the USA. Among the serotypes, PIV-3 was the most common (in more than half of the patients). Only $2 \%$ PIV-4 was detected. ${ }^{[34]}$ Rhinovirus is a member of the picornavirus family. It is one of the most common causes of the self-limited diseases called "the common cold." The major reservoir for rhinovirus is children. Only symptomatic treatment is recommended for infected patients. ${ }^{[35]}$

Pregnant women with influenza usually have an increased risk of developing serious complications. They may require hospitalization and ICU admission more frequently than non-pregnant women with influenza. The mortality rate may also be higher in this patient group; therefore, prompt antiviral treatment is recommended for pregnant patients with confirmed or suspected influenza, even up to 2 weeks into the postpartum period. Early treatment within 2 days of symptom onset has been associated with a more favorable clinical course and outcome. However, beginning treatment $>2$ days after symptom onset in patients not yet improving can be beneficial. ${ }^{[8,36]}$ In our study, 6 (9\%) 
patients were pregnant. Empirical oseltamivir treatment had been initiated within 2 days of symptom onset in 5 of them. Three had an influenza A infection. Only I pregnant patient who was brought to the emergency service late in the course of the disease required ICU follow-up, and unfortunately, she died due to complicated HINI influenza.

Young children with or without underlying diseases are at increased risk for hospitalization due to severe/complicated influenza. The classic symptoms of influenza may be absent in children. Complications of influenza, such as secondary bacterial infection (bacteremia, pneumonia, otitis media) and exacerbation of asthma may occur more frequently in this age group. ${ }^{[14]}$ Fortunately, all of the children in our study who were hospitalized with the diagnosis of influenza/influenza-like illness (SARI) survived.

Oseltamivir, zanamivir, and peramivir are the neuraminidase inhibitors that are active against both influenza $A$ and $B$ viruses. At that time, only oseltamivir was available in our country. Patients benefit most from antiviral therapy when it is initiated within the first 48 hours of disease. Therefore, treatment should be initiated as soon as possible. Neuraminidase inhibitors have been reported to shorten the duration of influenza symptoms by 1 to 3 days if administered within the first 24 to 48 hours. ${ }^{[37]}$ Oseltamivir and zanamivir are among the drugs classified in Pregnancy Category C. No adverse events caused by oseltamivir or zanamivir have occurred in pregnant women or their infants, but the available data are limited. ${ }^{[38]}$

Only fifteen (one-fifth) of the patients with severe influenza required follow-up in the ICU. Among the ICU patients, a total of 9 adults died. Winterbauer et al. ${ }^{[39]}$ reported that only 5 patients of II with severe influenza viral pneumonia survived after prolonged therapy in the ICU. In a study conducted in Turkey, half of the patients over 65 years of age were admitted to the ICU and one-third of them required mechanical ventilation. One-fourth died in the hospital. ${ }^{[18]}$ In our study, the case-fatality rate of HINI infection among hospitalized patients was $14 \%$.

In conclusion, two-thirds of the patients who were admitted to the hospital had an influenza A-HINI infection. Seven (16.7\%) of them required ICU follow-up. The HINI case-fatality rate was $14.3 \%$. Patients with risk factors who have severe influenza should be hospitalized. Oseltamivir treatment should be given early in the course to prevent mortality. Patients at risk for influenza should be vaccinated, and hospitals and medical staff should be prepared for the next influenza season.

Ethics Committee Approval

Approval has been obtained from the Kartal Dr. Lütfi Kırdar Training and Research Hospital Ethics Committee.

Informed Consent

Retrospective study.
Peer-review

Internally peer-reviewed.

Authorship Contributions

Concept: A.B., S.K., R.D., E.E.Ş.; Design: A.B., S.K., R.D.; Data collection \&/or processing: A.B., S.K., A.K., B.E.Ç., S.Ş.C., E.E.Ş.; Analysis and/or interpretation: A.B., S.K.; Literature search: A.B., A.K.; Writing: A.B., S.K., A.K.; Critical review: A.B., S.K., R.D., A.K., B.E.Ç., S.Ş.C., E.E.Ş.

Conflict of Interest

None declared.

\section{REFERENCES}

1. Dolin R. Influenza. In: Fauici A, Braunwald E, Kasper D, Hauser S, Longo D, Jameson JL, et al., editors. Harrison's Principles of Internal Medicine.17th ed. New York: McGraw Hill; 2008. p. 1127.

2. Centers for Disease Control and Prevention (CDC). Outbreak of swine-origin influenza A (H1N1) virus infection - Mexico, MarchApril 2009. MMWR Morb Mortal Wkly Rep 2009;58:467-70.

3. World Health Organization. Influenza-like illness in the United States and Mexico, 24 April 2009. Available at: http://www.who.int/ csr/don/2009_04_24/en/index.html. Accessed Apr 2009, 27.

4. World Health Organization. World now at the start of 2009 influenza pandemic. Available at: http://www.who.int/mediacentre/news/ statements/2009/h1n1_pandemic_phase6_20090611/en/index. html. Accessed Jun 11, 2009.

5. Fineberg HV. Pandemic preparedness and response-lessons from the H1N1 influenza of 2009. N Engl J Med 2014;370:1335-42.

6. Dawood FS, Iuliano AD, Reed C, Meltzer MI, Shay DK, Cheng PY, et al. Estimated global mortality associated with the first 12 months of 2009 pandemic influenza A H1N1 virus circulation: a modelling study. Lancet Infect Dis 2012;12:687-95. [CrossRef]

7. Lee EH, Wu C, Lee EU, Stoute A, Hanson H, Cook HA, et al. Fatalities associated with the $2009 \mathrm{H} 1 \mathrm{~N} 1$ influenza A virus in New York city. Clin Infect Dis 2010;50:1498-504. [CrossRef]

8. Jamieson DJ, Honein MA, Rasmussen SA, Williams JL, Swerdlow DL, Biggerstaff MS, et al; Novel Influenza A (H1N1) Pregnancy Working Group. H1N1 2009 influenza virus infection during pregnancy in the USA. Lancet 2009;374:451-8. [CrossRef]

9. Siston AM, Rasmussen SA, Honein MA, Fry AM, Seib K, Callaghan WM, et al; Pandemic H1N1 Influenza in Pregnancy Working Group. Pandemic 2009 influenza A(H1N1) virus illness among pregnant women in the United States. JAMA 2010;303:1517-25.

10. Louie JK, Acosta M, Samuel MC, Schechter R, Vugia DJ, Harriman $\mathrm{K}$, et al. A novel risk factor for a novel virus: obesity and 2009 pandemic influenza A (H1N1). Clin Infect Dis 2011;52:301-12.

11. Centers for Disease Control and Prevention (CDC). Weekly U.S. Influenza Surveillance Report. Available at: http://www.cdc.gov/flu/ weekly/. Accessed Dec 4, 2017.

12. World Health Organization. Flunet. Available at: http://www.who. int/influenza/gisrs_laboratory/flunet/en/. Accessed Dec 4, 2017.

13. European Commission. Commission Implementing Decision of 8 August 2012 amending Decision 2002/253/EC laying down case definitions for reporting communicable diseases to the Community network under Decision No 2119/98/EC of the European Parliament and of the Council. Official Journal of the European Union 2012;L262.

14. Boivin G, Hardy I, Tellier G, Maziade J. Predicting influenza infections during epidemics with use of a clinical case definition. Clin Infect Dis 2000;31:1166-9. [CrossRef] 
15. Harper SA, Bradley JS, Englund JA, File TM, Gravenstein S, Hayden FG, et al. Seasonal influenza in adults and children-diagnosis, treatment, chemoprophylaxis, and institutional outbreak management: clinical practice guidelines of the Infectious Diseases Society of America. Clin Infect Dis 2009;48:1003-32. [CrossRef]

16. Centers for Disease Control and Prevention. Guidance for clinicians on the use of RT-PCR and other molecular assays for diagnosis of influenza virus infection. Available at: http://www.cdc.gov/flu/professionals/diagnosis/molecular-assays.htm. Accessed Sep 6, 2017.

17. Lieberman D, Lieberman D, Shimoni A, Keren-Naus A, Steinberg $R$, Shemer-Avni Y. Identification of respiratory viruses in adults: nasopharyngeal versus oropharyngeal sampling. J Clin Microbiol 2009;47:3439-43. [CrossRef]

18. Tanriover MD, Bagci Bosi T, Ozisik L, Bilgin E, Güzel Tunçcan Ö, Özgen Ö, et al. Poor outcomes among elderly patients hospitalized for influenza-like illness. Curr Med Res Opin 2017:1-7. [CrossRef]

19. Nicholson KG. Clinical features of influenza. Semin Respir Infect 1992;7:26-37.

20. Su S, Chaves SS, Perez A, D'Mello T, Kirley PD, Yousey-Hindes K, et al. Comparing clinical characteristics between hospitalized adults with laboratory-confirmed influenza A and B virus infection. Clin Infect Dis 2014;59:252-5. [CrossRef]

21. Zhou H, Thompson WW, Viboud CG, Ringholz CM, Cheng PY, Steiner C, et al. Hospitalizations associated with influenza and respiratory syncytial virus in the United States, 1993-2008. Clin Infect Dis 2012;54:1427-36. [CrossRef]

22. Chaves SS, Aragon D, Bennett N, Cooper T, D'Mello T, Farley M, et al. Patients hospitalized with laboratory-confirmed influenza during the 2010-2011 influenza season: exploring disease severity by virus type and subtype. J Infect Dis 2013;208:1305-14. [CrossRef]

23. Nicholson KG, Kent J, Hammersley V, Cancio E. Acute viral infections of upper respiratory tract in elderly people living in the community: comparative, prospective, population based study of disease burden. BMJ 1997;315:1060-4. [CrossRef]

24. Monto AS. Medical reviews. Coronaviruses. Yale J Biol Med 1974;47:234-51.

25. Centers for Disease Control and Prevention (CDC). Respiratory syncytial virus activity-United States, 1999-2000 season. MMWR Morb Mortal Wkly Rep 2000;49:1091-3.

26. Hall CB, Weinberg GA, Iwane MK, Blumkin AK, Edwards KM, Staat MA, et al. The burden of respiratory syncytial virus infection in young children. N Engl J Med 2009;360:588-98. [CrossRef]
27. American Academy of Pediatrics. Respiratory syncytial virus. In: Kimberlin DW, Brady MT, Jackson MA, Long SS, editors. Red Book: 2015 Report of the Committee on Infectious Diseases. 30th ed. Elk Grove Village: 2015. p. 667.

28. van den Hoogen BG, de Jong JC, Groen J, Kuiken T, de Groot R, Fouchier RA, et al. A newly discovered human pneumovirus isolated from young children with respiratory tract disease. Nat Med 2001;7:719-24. [CrossRef]

29. Williams JV, Wang CK, Yang CF, Tollefson SJ, House FS, Heck JM, et al. The role of human metapneumovirus in upper respiratory tract infections in children: a 20-year experience. J Infect Dis 2006;193:387-95. [CrossRef]

30. Guido M, Tumolo MR, Verri T, Romano A, Serio F, De Giorgi M, et al. Human bocavirus: Current knowledge and future challenges. World J Gastroenterol 2016;22:8684-97. [CrossRef]

31. Moesker FM, van Kampen JJ, van der Eijk AA, van Rossum AM, de Hoog M, Schutten M, et al. Human bocavirus infection as a cause of severe acute respiratory tract infection in children. Clin Microbiol Infect 2015;21:964.e1-8. [CrossRef]

32. Ison MG. Respiratory viral infections in transplant recipients. Antivir Ther 2007;12:627-38.

33. Russell E, Ison MG. Parainfluenza Virus in the Hospitalized Adult. Clin Infect Dis 2017;65:1570-6. [CrossRef]

34. Fry AM, Curns AT, Harbour K, Hutwagner L, Holman RC, Anderson LJ. Seasonal trends of human parainfluenza viral infections: United States, 1990-2004. Clin Infect Dis 2006;43:1016-22.

35. Hendley JO. Rhinovirus colds: immunology and pathogenesis. Eur J Respir Dis Suppl 1983;128:340-4.

36. Mosby LG, Rasmussen SA, Jamieson DJ. 2009 pandemic influenza A (H1N1) in pregnancy: a systematic review of the literature. Am J Obstet Gynecol 2011;205:10-8. [CrossRef]

37. Cooper NJ, Sutton AJ, Abrams KR, Wailoo A, Turner D, Nicholson KG. Effectiveness of neuraminidase inhibitors in treatment and prevention of influenza $A$ and $B$ : systematic review and meta-analyses of randomised controlled trials. BMJ 2003;326:1235. [CrossRef]

38. Tanaka T, Nakajima K, Murashima A, Garcia-Bournissen F, Koren G, Ito S. Safety of neuraminidase inhibitors against novel influenza A (H1N1) in pregnant and breastfeeding women. CMAJ 2009;181:55-8. [CrossRef]

39. Winterbauer RH, Ludwig WR, Hammar SP. Clinical course, management, and long-term sequelae of respiratory failure due to influenza viral pneumonia. Johns Hopkins Med J 1977;141:148-55.

\section{5-2016 Influenza Sezonunda Ağır İnfluenza/Akut Solunum Yolu Enfeksiyonu Nedeniyle Yatış Gerektiren Hastaların Klinik Seyri ve Etkenleri}

Amaç: Ağır influenza kliniğiyle 2015-2016 yılında yatırılan hastaların etiyolojik profilini, klinik seyrini ve sonuçlarını belirlemeyi amaçladık.

Gereç ve Yöntem: Hastanemize I Aralık 2015-15 Mart 2016 tarihleri arasında ağır influenza kliniğiyle yatırılan hastalar çalışmaya dahil edildi. Dispne, takipne, taşikardi, hipotansiyon, hipoksi, mental durum değişikliği, ağır dehidratasyon, akciğer grafisinde bronkopnömoni/pnömoni varlığı "ağır influenza" olarak değerlendirildi. Hastaların nazofarengeal aspirat örnekleri ters transkriptaz-polimeraz zincir reaksiyonu tekniği ile solunum virüsleri açısından tarandı.

Bulgular: Toplam 95 nazofarengeal aspirat örnekleri incelenen hastanın 65'i (\%68.4, 38'i erişkin, 27'si çocuk) virüs-pozitifdi. Etken virüslerin dağılımı şöyleydi: 42'si (\%64.6) influenza A (HINI), 9'u (\%।3.8) influenza A (H3N2), 5’i (\%7.7) coronavirus. Altı (\%9.2) hasta gebeydi. Gebelerden sadece biri yoğun bakım ünitesinde (YBÜ) izlem gerektirdi ve HINI influenza nedeniyle kaybedildi. On beş (\%23, I4 yetişkin, bir çocuk) hasta YBÜ'de izlendi. Bunlardan dokuzu kaybedildi [7'si influenza A (6 HINI, I H3N2), I'i HMPV, I'i coronavirus], tüm çocuklar şifayla taburcu edildi. Hastanemize yatırılarak izlenen HINI enfeksiyonunda olgu fatalite hızı \%।4.3'dü.

Sonuç: Hastaneye yatırılan hastaların üçte ikisinde influenza A-HINI enfeksiyonu vardı. Yedisi (\%।6.7) YBÜ'de izlendi. Bunlarda HINI olgufatalite hızı \% 14.3. Ağır influenza için risk faktörü olan hastalar yatırılarak izlenmelidir.

Anahtar Sözcükler: Ağır akut solunumyolu enfeksiyonu; grip; HINI; influenza; solunum yolu virüsleri. 